\title{
PERANCANGAN KEAMANAN SISTEM MENGGUNAKAN ALGORITMA HONEYPOT PADA APLIKASI KRS ONLINE (STUDI KASUS : SEKOLAH TINGGI TEKNOLOGI ADISUTJIPTO)
}

\author{
Yoris Setyawan, Haruno Sajati, Bambang Sudibya \\ Teknik Informatika STTA Yogyakarta \\ Informatika@stta.ac.id
}

\begin{abstract}
Many colleges already apply web based academic information system use internet connection, so it is need a system security to protect from attacks such as SQL Injection and Brute Force. Honeypot is a system security which devide two system that are: original and fake system. Original system used by user to access academic information system that source from correct database. While fake system used to separate hacker and user. Hackers who try to enter with SQL Injection is send to fake system directly which has wrong data. This fake system seems correct and all action that was happened in will be noted on log history. When hacker try some password ese Brute Force, system will reset user password automatically. This system already test with 79 times SQL Injection and 29 times Brute Force attack. All attacks can handle nicely with honeypot algorithm.
\end{abstract}

Keywords: SQL injection, brute force, honeypot, system security

\section{Latar Belakang Masalah}

Sistem informasi akademik KRS (Kartu Rencana Studi) merupakan salah satu kemudahan bagi seorang mahasiswa untuk menginputkan matakuliah yang akan diambil pada setiap semester. Tetapi dibalik kemudahan sistem yang canggih itu perlu. Dengan sistem keamanan menggunakan honeypot diharapkan dapat melindungi sistem yang sedang berjalan.

Dengan adanya sistem keamanan honeypot diharapkan dapat melindungi sistem informasi akademik (KRS) secara maksimal dan akurat terutama dari serangan-serangan seperti SQL injection ataupun seperti serangan Brute force.

\section{LANDASAN TEORI}

\section{Tinjauan Pustaka}

a. Banking Security using Honeypot

Dalam perancangan dan pembuatan sistem keamanan pada KRS online ini terdapat penelitian pada jurnal karya Sandeep Chaware dari D.J.Sanghvi College of Engineering, Mumbai yang membahas tentang banking security using honeypot. Implementasi honeypot digunakan untuk memonitor dan mendeteksi menggunakan Network Intrusion Detection System (NIDS) atau Intrusion Detection Systems (IDS). Pada penelitian ini serangan hanya dipusatkan untuk SQL injection dan brute force yang diarahkan ke aplikasi KRS online. Sedangkan untuk monitoring tindakan hacker semua telah tercatat pada log history yang telah disediakan. 
b. Honeyweb: a web-based high interaction client honeypot

Terdapat penelitian pada jurnal karya Nageshri B Karhade dari Vidyavardhini's College of Engineering and Technology, Mumbai University yang membahas Honeyweb: a web-based high interaction client honeypot. Pada penelitian ini serangan difokuskan pada tipe serangan $S Q L$ injection yang nantinya diarahkan ke server palsu oleh honeypot. Sedangkan untuk tipe serangan brute force sistem akan mengganti password user dengan yang baru setelah 5 kali gagal login.

\section{Honeypot Security}

Honeypot merupakan sebuah sistem atau komputer yang sengaja "dikorbankan" untuk menjadi target serangan dari hacker. Komputer tersebut melayani setiap serangan yang dilakukan oleh hacker. Metode ini ditujukan agar administrator dari server yang akan diserang dapat mengetahui trik penetrasi yang dilakukan hacker serta bisa melakukan antisipasi dalam melindungi server yang sesungguhnya.

\section{PERANCANGAN SISTEM}

\section{Perancangan Perangkat lunak}

a. Diagram Konteks

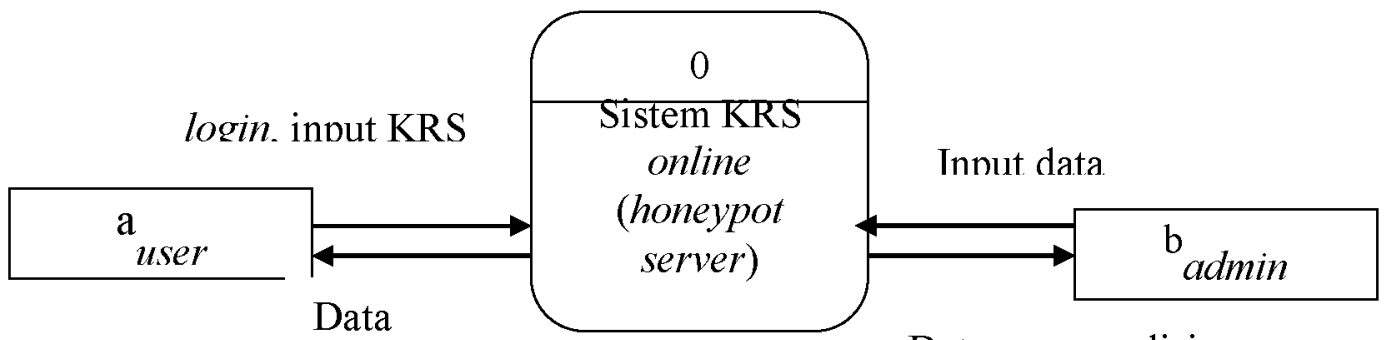

Data user analisis

Gambar 1 Diagram Konteks

b. DFD Level 1 Aplikasi KRS Online

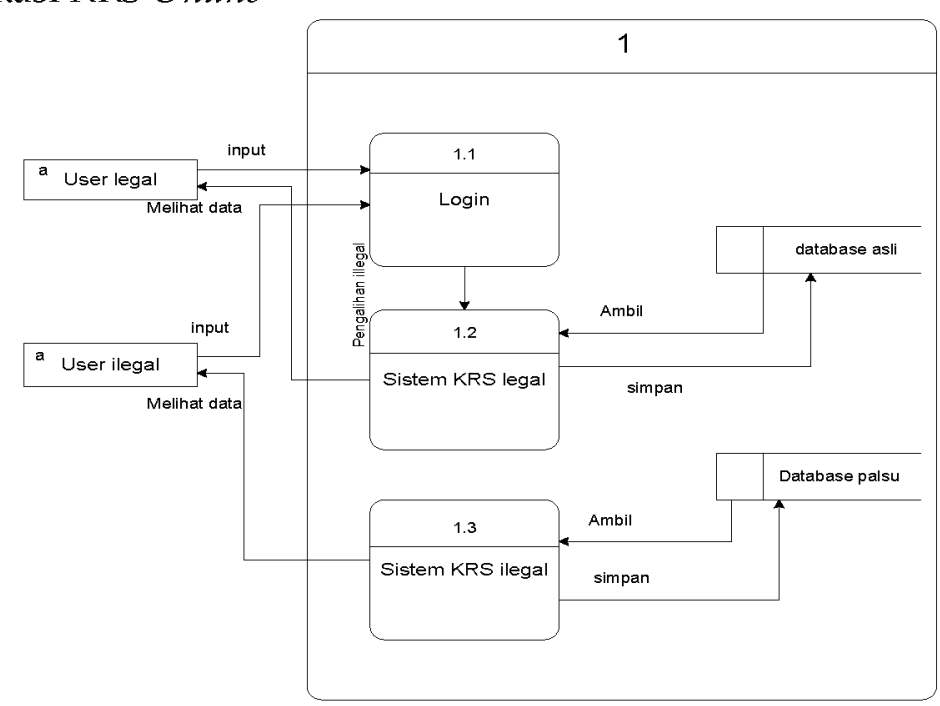

Gambar 2 DFD Level 1 


\section{Algoritma Honeypot}

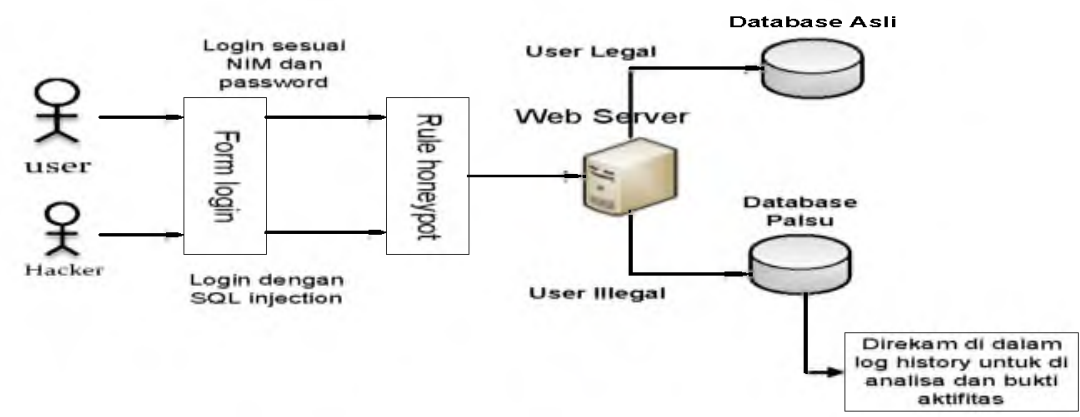

Gambar 3 Algoritma Honeypot

Pada Gambar 3 alur algoritma honeypot dapat dilihat saat user login dengan nim dan password sesuai dengan database maka rule honeypot akan memeriksa login user yang masuk benar sesuai dengan di database atau tidak. Jika benar maka honeypot akan menganggap user login dengan legal sehingga dapat diarahkan menuju ke sistem asli. Sedangkan saat hacker yang login dengan SQL injection maka honeypot akan memeriksa nim dan password yang digunakan untuk login, maka hacker akan langsung diarahkan ke sistem palsu. Selanjutnya segala aktifitas di dalam sistem palsu ke dalam log history, nantinya menjadi jejak yang ditinggalkan oleh hacker sehingga admin dapat menganalisa apa yang terjadi di dalam sistem palsu tersebut.

\section{IMPLEMENTASI}

\section{User Legal}



Gambar 4 Login User

Form login digunakan untuk user masuk ke dalam sistem KRS online dengan memasukkan nim dan password yang telah didaftarkan di form registrasi sebelumnya. Form login memiliki satu tombol submit dan dua link, yaitu registrasi dan reset password. Tombol submit digunakan untuk mengecek nim dan password yang telah diisi dengan data di dalam database

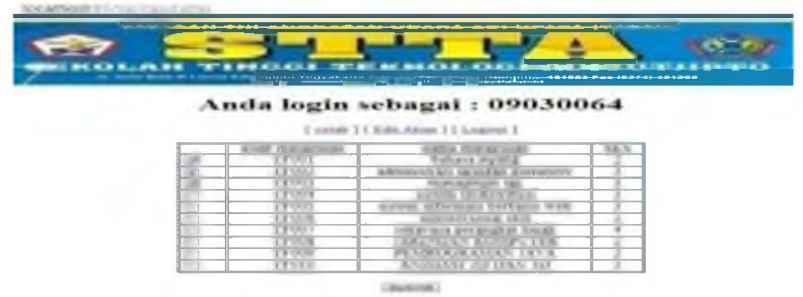

Gambar 5 Input Matakuliah

Form input matakuliah merupakan sistem utama yang dilindungi oleh honeypot, form input berisikan daftar-daftar matakuliah yang akan diambil oleh $u s e r$.

\section{Pengalihan User Illegal}


Sistem yang digunakan untuk mengecoh hacker yang akan masuk ke dalam sistem dengan cara login menggunakan SQL Injection. Sistem palsu ini menggunakan database mysql sebagai penyimpanan data palsu yang merupakan pencerminan dari database asli.

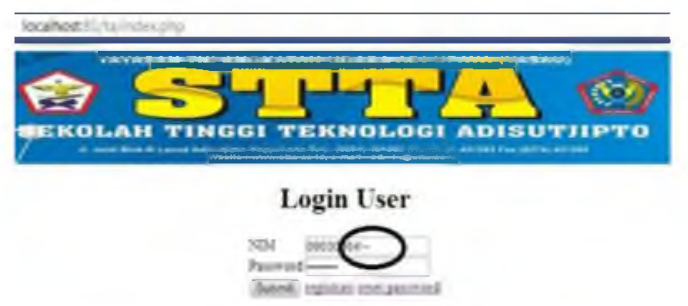

Gambar 6 Pengalihan User Illegal

Form login terdapat pada Gambar 6 menunjukkan proses login yang dilakukan hacker dengan menggunakan serangan $S Q L$ injection. Konsep $S Q L$ injection menyisipkan perintah $S Q L$ kepada suatu statement $S Q L$ yang ada pada aplikasi yang sedang berjalan.

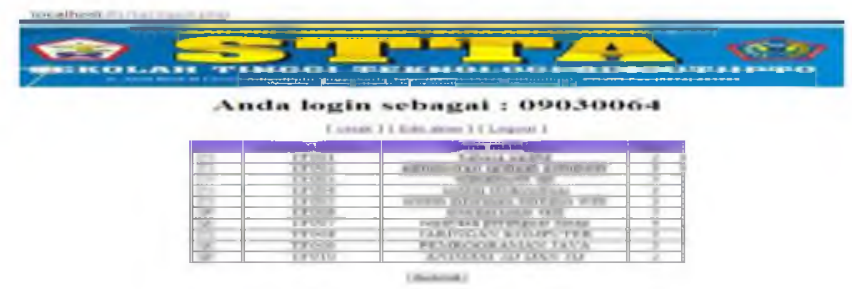

Gambar 7 Tampilan Pengalihan User Illegal

Tampilan pada sistem palsu dibuat sama persis dengan tampilan di sistem asli untuk mengecoh hacker yang menyerang dengan SQL injection bahkan alamat web dibuat sama persis dengan yang asli. Semua aktifitas hacker di dalam sistem palsu akan terekam dan tersimpan dalam log history

\section{Pengujian}

a. Uji Coba SQL Injection

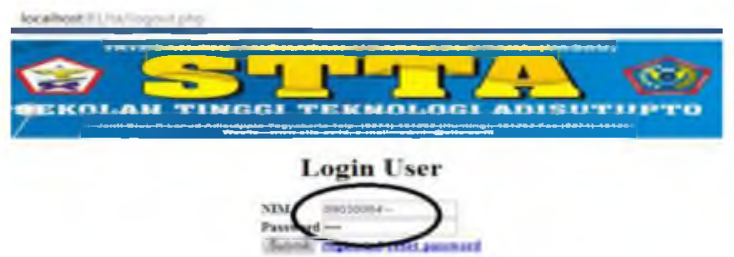

Gambar 8 Login Dengan SQL injection

Proses login yang telah disisipkan perintah SQL injection pada nim user dengan menambahkan command "'-- ". Command ini berfungsi mengabaikan command-command setelah nim yang ada di dalam script web. Sehingga hanya dengan mengisikan nim 09030064"-maka hacker akan dapat masuk ke dalam sistem, disini peran honeypot akan bekerja. Honeypot akan menyaring setiap user yang login ke dalam sistem jika nim dan password yang digunakan benar maka user akan diarahkan ke dalam server sedangkan jika hacker login dengan $S Q L$ injection maka honeypot akan mengarahkan hacker langsung ke sistem palsu untuk mengecoh hacker yang masuk. Untuk password dapat diisi bebas karena tidak berpengaruh terhadap nim yang telah di-injection. 


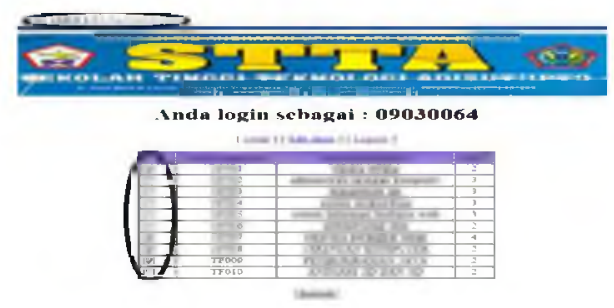

Gambar 9 Tampilan Setelah di Hack

b. Uji Coba Brute Force

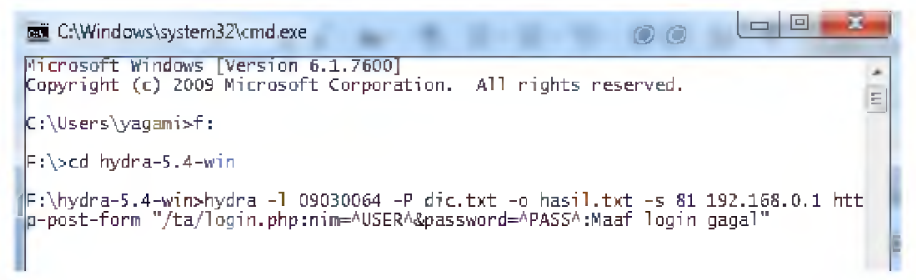

Gambar 10 Mulai Brute Force

Ini merupakan tahap untuk menggunakan software hydra yang digunakan untuk brute force. Untuk menjalankan software ini menggunakan command prom atau CMD sesuaikan directory tempat dimana software hydra disimpan. Command untuk menggunakan software ini,

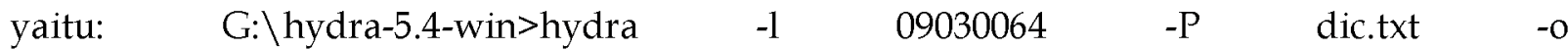
hasil.txt -s 81 192.168.0.1 http post form "/ta/login.php:nim=^USER^\&password=^PASS^:Maa f login gagal".



Gambar 11 Hasil Brute Force

\section{ANALISA}

Dari serangan yang terjadi diperoleh data statistik berupa total serangan yang terjadi dan detail serangan berupa tanggal dan jam serangan selama pengujian.



Gambar 12 Grafik Total Serangan

Dari Gambar 12 diketahui total serangan telah terjadi 79 kali SQL injection dan 29 kali serangan brute force. Dengan pembagian, nim 09030020 diserang menggunakan SQl injection sebanyak 2 kali dan 1 kali dengan brute force, nim 09030044 diserang menggunakan SQl injection sebanyak 2 kali dan 1 kali dengan brute force, nim 09030076 diserang menggunakan SQl injection sebanyak 8 kali dan 1 kali dengan brute force, nim 09030006 diserang menggunakan SQl injection sebanyak 1 kali, nim 09030064 diserang menggunakan SQl 
injection sebanyak 39 kali dan 15 kali dengan brute force, nim 09030071 diserang menggunakan SQl injection sebanyak 27 kali dan 11 kali dengan brute force.

\section{KESIMPULAN DAN SARAN}

\section{Kesimpulan}

1. Penerapan algoritma honeypot pada sistem KRS dapat digunakan sebagai tindakan pencegahan untuk upaya gangguan keamanan dengan SQL injection dan brute force.

2. Algoritma honeypot berhasil membedakan antara user legal dan user illegal.

3. Serangan dari pengguna illegal yang sama sebanyak lima kali akan ditindak dengan cara membuat password baru secara otomatis dan random khusus serangan brute force.

\section{Saran}

Kelemahan dari sistem ini yaitu honeypot yang dirancang tidak dapat menahan serangan berupa virus atau beberapa serangan yang langsung ditujukan ke operating system seperti denial of service dan ping of death. Saran untuk mengatasi hal tersebut dengan membangun keamanan honeypot dengan fungsi firewall. Sehingga honeypot dapat membedakan serangan dan dialihkan ke server palsu.

\section{DAFTAR PUSTAKA}

Chaware, Sandeep., 2011., Banking Security Using Honeypot, International Journal of Security and Its Applications Vol. 5 No. 1 hal 31, D.J.Sanghvi College of Engineering, Mumbai, India.

Jogiyanto, MBA, Akt., Analisis dan Desain Sistem Informasi: Pendekatan Terstruktur Teori Dan Praktik Aplikasi Bisnis, Penerbit Andi, Yogyakarta.

Patil, Sainath, dkk., 2012., Honeyweb: a web-based high interaction client honeypot, International Journal of Engineering Research and Applications (IJERA) ISSN: 2248-9622, Vidyavardhini's College Of Engineering And Technology, Mumbai, India.

Utdirartatmo, Firrar., 2005., Menjebak Hacker dengan Honeypot, Penerbit Andi offset, Yogyakarta. 